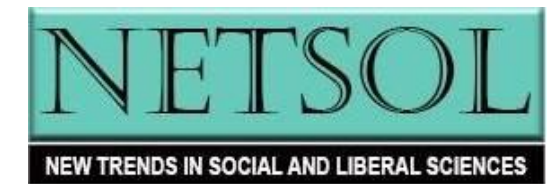

An Interdisciplinary Journal

http://www.netsoljournal.net/

Volume 6, Issue 1, pp.70-73, Spring 2021

https://doi.org/10.24819/netsol2021.05

Date Submitted: January 19, $2021 \quad$ Date Accepted: May 24, 2021

\title{
Review Essay: The Beginnings of Civilization
}

Nicola Crüsemann, Margarete van Ess, Markus Hilgert, and Beate Sialje, Uruk: First City of the Ancient World. Eds. Nicola Crüsemann, Margarete van Ess, Markus Hilgert, and Beate Sialje. English translation from the German by Timothy Potts. Los Angeles: The J. Paul Getty Museum, 2019.

Ariane Thomas and Timothy Potts, Mesopotamia: Civilizations Begins. 2020. Eds. Ariane Thomas and Timothy Potts. Los Angeles: The J. Paul Getty Museum, 2020.

Key Words: Uruk, Mesopotamia, Fertile Crescent, Asia, Civilization, Sumerian, Akkadian

\section{Walter C. Clemens, Jr. Boston University, Professor Emeritus}

What can contemporary social scientists learn from ancient history? Key features of modern civilization began in the fertile crescent of today's Middle East many thousands of years ago. Thanks to geography and other factors, these innovations spread-east and west. Not just agriculture and engineering but monotheistic religion and alphabetic writing took root there. Parallels to or offshoots of Sumerian culture emerged in the Indus River, Persia, and Egypt. Their distinctive ways of life took shape, waxed, and then waned.

Social scientists who try to keep up with a world in turmoil by listening to the BBC or reading Le Monde may be tempted to ask: "How did all this begin and where are we going?" The Singapore-based political analyst Parag Khanna answers: "Asia." Civilization began in Western Asia and is now being shaped by "Asianization" of the planet. (See Khanna, The Future is Asian,

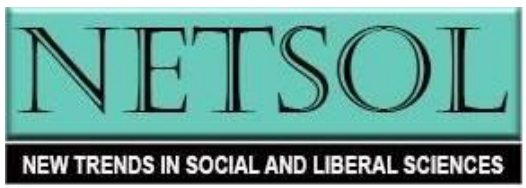


2019). Whether or not Khanna's hypothesis about the future proves correct, the importance of Western Asia in global history is documented in the books Uruk and Mesopotamia.

The origins of civilization probably go back six to seven million years when the human lineage diverged from chimpanzees and bonobos as some primates started to walk on their hind legs. According to David A. Raichlen and Gene E. Alexander, "Why Your Brain Needs Exercise," (Scientific American, January 2020), our ancestors for millions of years were probably relatively sedentary bipedal apes who ate mainly plants. By two million years ago, as the climate cooled and habitats dried out, at least one group of ancestral humans began to hunt other animals and gather plant foods. Hunting and gathering demands more aerobic activity than the sedentary lifestyle of most apes. The effects of cognitively engaged exercise on the brain probably helped to make early humans different from other primates

Balancing on two legs (sometimes just one) and foraging for food required our ancestors to cope effectively with a range of challenges. They became more fit - better able to cope with a range of complex challenges and opportunities. Hunter-gathers had to navigate and find food, often during fast-paced treks extending more than twenty kilometers. At high speeds multitasking becomes more difficult. The brain has to respond quickly to an array of challenges during and after foraging to maximize the chances of finding food and helping family members to consume it. Still, our ancestors continued to depend on hunting and gathering for nearly two million years until the advent of farming and herding some 15,000 to 10,000 years ago.

In Mesopotamia and Asia Minor, the advent of basic farming tools helped humans evolve from hunter-gatherer tribes into more settled agricultural communities. Some 15,000 years ago, as Khanna outlines world history, the Natufian people in the eastern Levantine region began to grind and bake wheat into bread. Fortifications in Byblos, Aleppo, and Jericho reveal settlements - small cities-dating to 7000 BC. By 3800 BC the great Sumerian city-states were thriving near the confluence of the Tigris and Euphrates rivers. Their ability to collaborate for shared goals showed a still greater form of societal fitness, one that helps explain how humans have dominated life on earth.

The laws, architecture, farming practices, and legends developed in the third and fourth millennia BCE shaped the ways of life in neighboring regions. Across the centuries these innovations also informed and energized the West and, indeed, global civilization. The Sumerians were responsible for many of the most important inventions and concepts now taken for granted. They essentially "invented" time by dividing day and night into 12-hour periods, hours into 60 minutes, and minutes into 60 seconds. Their other innovations and inventions include the first schools, governmental bureaucracy, written laws, monumental architecture, and irrigation techniques. The oldest heroic epic, Gilgamesh, passed on from one Mesopotamian culture to another, provided the earliest version of the tale of the Great Flood and other biblical narratives.

The ways in which civilization began and spread are detailed in Uruk and Mesopotamia. Each of these volumes, published by the J. Paul Getty Museum, contains deep historical analysis illustrated by detailed maps, photos of ancient buildings and statues, and reproductions of lavish artwork in vibrant color. For many readers, these books will provide a deep learning experience achieved with great pleasure. For those of us who struggle to read a foreign language, even those in our own lettering, there will arise a feeling of awe at the ability of some scholars to cope not

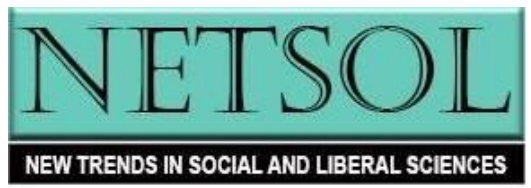


only with ancient Greek but with Sumerian and Akkadian writing carved out in cuneiform on tablets now broken but fitted together by archeologists determined to get to the bottom of things. While many of today's social scientists and historians strain to sift through dusty archives or scan online materials on desktop or hand-held computers, other researchers have found their texts and illustrations by digging through layers of dirt, stones, and debris.

The director of the Getty Museum, Timothy Potts, writes in the introduction to Uruk that this "mother city" of ancient Sumer (later known as Babylonia and located in today's southern Iraq) was the earliest site where the key social, cultural, economic, and technological elements of Mesopotamian civilization emerged and endured for the next three millennia (a bit longer than the less than three hundred years of the United States). The dynamics of Uruk help us understand the origins of urbanization around the world. Still, its relevance to a multiplicity of disciplines from sociology to linguistics and art history have not been widely appreciated. Why? All the preliminary excavation reports and much of the secondary literature were published mostly only in German. Uruk first appeared in German as the catalog for an exhibition at the Pergamon Museum in Berlin.

The second book discussed here, Mesopotamia: Civilization Begins, was issued on the occasion of an exhibition at the Getty Villa in Malibu, California, in 2020. The book is adapted from the French version published in 2016 to accompany an exhibition at the Musée du LouvreLens in 2016-2017. The two books provide a sort of one-two punch as they start with the mother city and then illuminate the entire region. A chapter in Mesopotamia by Pascal Butterlin traces the movement from Uruk to Babylon. A chapter by Zainab Bahrani describes the dynamics from the birth of the state to great empires. Michael Seymour details how ancient Mesopotamia is reflected in modern imagery (from Babylon's "hanging gardens" to Rastafarians" "Rivers of Babylon").

In the third century BC, a Babylonian priest wrote a history of his land in Greek so the followers of Alexander the Great could understand what they had conquered and occupied. He explained that, in the distant past, men "lived without law just as wild animals." But a sage in the form of a sea creature appeared and gave the men of Babylon (nothing said of the women) knowledge of letters, sciences, and crafts. It taught them how to found cities and establish temples, how to introduce laws and measure the land, how to plant seeds and harvest fruit. In short, "it taught men all things conducive to a settled and civilized life." From that time, the priest historian wrote, "nothing further has been discovered." This account, Potts writes-written some three thousand years after the founding of Uruk-offers a valuable introduction to early urbanization. Another recent work by Ben Wilson, Metropolis: A History of the City, Mankind's Greatest Invention (2020), joined the limited corpus of books on the beginnings of civilization.

It may come as a surprise to some proponents of "America first," but trade has long been a key to the cross-cultural exchanges that have enriched civilized life and general well-being. Thus, the city-states in Sumer ("land of the civilized kings") in the fertile crescent produced food surpluses but needed minerals and wood, which they got from elsewhere. Earlier research by Timothy F. Potts (Mesopotamia and the East, 1994) shows the patterns of Sumerian trade over several millennia. He points out that Sumer owed its existence to the rivers flowing through it. The Tigris and Euphrates Rivers also served as the principal arteries of trade and communication between Babylonia and the north-west. To the south-east the Euphrates linked Sumer with the Gulf and the lands beyond, including the Indus and perhaps also Egypt. Land communication and

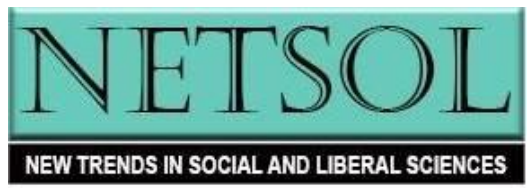


transport between Mesopotamia and highland Iran was severely limited by geography, climate and the availability of water. The main road from Mesopotamia across Iran followed the line of the "Great Khorasan Road," as it was called by the Arab geographers. In the Neo-Assyrian period access to Iran from northern Mesopotamia was achieved along three main routes which were probably already in use in the third millennium. Perhaps the most important route eastwards from Sumer in the third millennium was the road leading through Fars to Anšari, the highland capital of Elam.

The innovations cultivated between or near to the Tigris and Euphrates rivers spread in all azimuths. They joined with cultural advances made in the valleys of the Indus and Ganges and the great rivers of China to form a vast east-west exchange of goods, ideas, and practices. Thanks to geography and other factors, east-west transmission was much easier than north-south Thus, the astronomy and writing of the Mayans did not reach Europe until Spaniards penetrated the Americas, along with horses and cows as well as guns, germs, and steel-all previously unknown there. (Jared Diamond, Guns, Germs, and Steel: The Fates of Human Societies, 1997). In time, Europeans built on fertile crescent innovations but energized them with an explosive power fueled by the openness embodied in the Renaissance, Reformation, Enlightenment, and Industrial Revolutions. The Age of Exploration was not the only reason why European power began to surpass Asian and Middle Eastern. A new outlook - an openness to all the possibilities of science, technology, the arts, and society itself — transformed the West. (Johan Norberg, Open: The Story of Human Progress, 2020). The Reformation spawned three revolutions that nurtured opennessdemands for mass literacy, free thought, and respect for individual dignity (Walter C. Clemens, Jr. "Keys to Human Development: The Baltic Miracle," NETSOL [Fall 2020]: 1-29.)

Openness in the West has persisted for more than five centuries-making its outlook far more liberating than what has prevailed in most other civilizations, including Communist China and technocratic Singapore. The global future will not be Asian or American or European but some kind of admixture. Some Westerners have tried to share aspects of the Enlightenment with peoples of today's Middle East. Starting in Beirut in 1862 American Universities have been established in many parts of the Middle East. But these Western voices and their impact have been negated by imperial bullying and, in recent decades, by bombs and missiles. If the lands between the Tigris and Euphrates laid the foundations for today's global civilization, Western powers have decimated theirs.

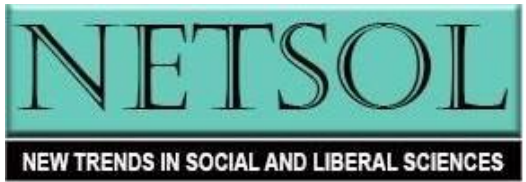

